\title{
VALORES E EFEITOS PASSIONAIS EM JOGO EM “A ROUPA NOVA DO REI": UMA ANÁLISE SEMIÓTICA
}

\author{
PASSIONAL VALUES AND EFFECTS AT STAKE ON "THE KING'S NEW \\ CLOTHES": \\ A SEMIOTIC ANALYSIS
}

\author{
Suany Oliveira MORAES ${ }^{1}$ \\ UFMS - Universidade Federal de Mato Grosso do Sul
}

\begin{abstract}
RESUMO: A presente investigação tem por objetivo analisar, sob o ponto de vista da Semiótica de linha francesa, também denominada de Semiótica Greimasiana, o conto de fadas "A Roupa Nova do Rei" do escritor dinamarquês Hans Christian Andersen (1805-1875). Trata-se da análise do percurso gerativo de sentido, em que as três instâncias ou níveis do plano de conteúdo desta narrativa serão examinados para fins de apreensão dos efeitos de sentidos modais e passionais que emanam das relações entre os sujeitos e entre os sujeitos e os objetos valor. Portanto, valores modais e passionais
\end{abstract} em jogo na narrativa serão aqui abordados nos níveis: fundamental, narrativo e discursivo.

PALAVRAS-CHAVE: Semiótica; Greimas; Narrativa; Conto de Fadas; Valores; Efeito Passional.

ABSTRACT: The aim of the present research is to examine the fairytale "The King's New Clothes" by the Danish writer Hans Christian Andersen (1805-1875), from the point of view of French Semiotics, also called Greimasian Semiotics. It is the analysis of the generative course of meaning, in which the three instances or levels of content plan of this narrative will be examined for the purpose of seizing the effects of modal and passional meanings which emanate from the relationships among individuals and between individuals and objects-value. Therefore, modal and passional values at stake in the narrative will be discussed here in the fundamental, narrative and discursive levels.

KEYWORDS: Semiotics; Greimas; Narrative; Fairytale; Values; Passional Effect.

Narciso acha feio o que não é espelho.

Sampa, Caetano Veloso

\section{Introdução}

O conto infanto-juvenil "A Roupa nova do Rei”, escrito por Hans Christian Andersen (1805-1875), é uma das produções narrativas mais conhecidas deste autor dinamarquês (UOL EDUCAÇÃO, 2013).

Estruturalmente, este conto de fadas é relativamente longo, com três personagens principais (o Rei e dois trapaceiros) e outros secundários (os empregados do Rei, ou seja, os

\footnotetext{
${ }^{1}$ Professora de Língua Portuguesa do CMCG - Colégio Militar de Campo Grande (MS) / Mestre em Estudos de Linguagens na UFMS - Universidade Federal de Mato Grosso do Sul.
} 
súditos do reino e uma criança, que exerce um papel muito importante no desenrolar da história). A narrativa, basicamente, põe em xeque valores que se contrapõem em relação ao sujeito principal. Tem-se nela, claramente, uma oposição mínima de base: Vaidade $\mathrm{x}$ Humildade. São também traçados os percursos do sujeito em todas as suas fases actanciais, a saber: a manipulação, a competência, a perfórmance e a sanção. Além disso, o conto elucida um valor moral muito importante na sociedade: o desapego aos valores materiais, $o$ desprendimento e, por consequência, a humildade. O Rei aprende uma lição, um valor moral. De sujeito apegado a roupas, exibido em suas vestes, passa a ser um sujeito desapegado, desprendido de valores fúteis. E é por meio da paixão da vergonha que ele se transforma. $\mathrm{Ou}$ seja, é preciso que ele seja castigado, humilhado e, mais precisamente, sentir-se envergonhado para assumir o erro e admitir uma nova forma de dar valor às roupas e às vestimentas que costumava usar.

Por razões metodológicas e para fins de análise, esta narrativa será fragmentada em cinco partes ou aqui chamados de Momentos Narrativos, e estes serão especialmente destacados com recuo e itálico para melhor identificação. Sua reprodução poderá ser integralmente lida ao final deste artigo. Tal divisão centra-se nas ações e nos efeitos passionais (estados de alma) do protagonista da história - o Rei - e o critério adotado para a promoção do corte no fluxo da narrativa foram as modalizações veridictórias; o jogo do ser e do parecer, modalizações estas apreendidas o tempo todo na narrativa, desde a situação inicial, passando pelo desenvolvimento e pelo clímax, até chegar ao desfecho.

Tem-se, neste trabalho, uma situação inicial transformada pelas modalidades veridictórias: o que é, ao final da narrativa, deixa de ser, transforma-se e é nisso que consiste o valor moral do discurso, ou seja, a história termina bem (parte-se de uma categoria disfórica para uma categoria eufórica, com as sanções aplicadas a quem deve e o sujeito Rei acaba por ser moralizado. Neste sentido, não temos uma circularidade na história, pois ao final dela, a situação inicial não é retomada e sim transformada, invertida.

A partir de agora, aplicaremos a teoria semiótica de linha francesa (greimasiana) como método de análise que tem por objetivo, de acordo com Gregolin (1995, p. 18): “[...] analisar a construção e a organização dos discursos e dos textos através de um conjunto de regras." Regras estas que compõem um percurso gradual da construção de sentido, o percurso gerativo de sentido.

\section{O nível fundamental: o mais simples e abstrato dos níveis do percurso}

A partir de agora, teremos o início da narrativa de Hans Andersen ou o Momento Narrativo 1 (MN1):

Era uma vez um rei, tão exageradamente amigo de roupas novas, que nelas gastava todo o seu dinheiro. Ele não se preocupava com seus soldados, com o teatro ou com os passeios pela floresta, a não ser para exibir roupas novas. Para cada hora do dia, tinha uma roupa diferente. Em vez de o povo dizer, como de costume, com relação a outro rei: "Ele está em seu gabinete de trabalho", dizia "Ele está no seu quarto de vestir".

Esta é a situação inicial do texto, ou seja, o primeiro momento da narrativa. Temos um sujeito (Rei) interessado "exageradamente" por um determinado objeto valor (roupa). Ele é um sujeito desinteressado de outros valores importantes para o cargo ou função social que ocupa, tais como: segurança, cultura ou entretenimento de seu povo. Neste MN1, o sujeito Rei parece vaidoso, apegado em roupas e, de fato, o é. Aqui se estabelece uma oposição mínima 
de base da narrativa: vaidade $\mathbf{x}$ humildade. São estes valores que estarão em jogo na narrativa e com os quais o Rei vai compartilhar até que a situação inicial se inverta. É importante notarmos que a vaidade (representada pelo objeto valor roupa) é eufórica para o sujeito Rei e a humildade ou modéstia é disfórica, pelo menos neste momento, já que o Rei não fazia outra coisa senão se preocupar com roupas para exibir-se. Voltaremos a analisar esta transformação fórica ao final da narrativa, em que a vaidade torna-se disfórica e a humildade ou modéstia passa a ser fórica para o Rei. Em outras palavras, veremos, durante a análise, como o Rei, que inicialmente afirma a vaidade, deixa de afirmá-la, para então afirmar a humildade.

\section{O nível narrativo: o nível das ações ou da sucessão de acontecimentos}

Este é o Momento Narrativo 2 (MN2). Basicamente, este recorte mostra uma transformação na ordem natural do reino, as coisas começam a mudar, pois dois outros sujeitos (os trapaceiros ou impostores) "arquitetam" um plano para enganar o Rei e com isso conseguirem dinheiro, por meio de trapaças. $\mathrm{O}$ antissujeito, que é também protagonista, age de modo a manipular não só o Rei, mas os seus súditos e conselheiros, tendo como valor de troca o objeto valor que é tão caro para o monarca: peças de roupas. É pela busca de um objeto que a trama se faz e também pela oposição do sujeito com o antissujeito. Vejamos o seguinte fragmento:

A vida era muito divertida na cidade onde ele vivia. Um dia, chegaram hóspedes estrangeiros ao palácio. Entre eles havia dois trapaceiros. Apresentaram-se como tecelões e gabavam-se de fabricar os mais lindos tecidos do mundo. Não só os padrões e as cores eram fora do comum, como também as fazendas tinham a especialidade de parecer invisíveis às pessoas destituídas de inteligência, ou àquelas que não estavam aptas para os cargos que ocupavam.

Temos de considerar a primeira relação entre o sujeito Rei com o objeto valor roupa. Trata-se de um enunciado de estado, ou seja, o Rei está em conjunção com seu objeto. Ele é um sujeito "virtualizado", pois quer estar em conjunção com seu objeto o tempo todo. E adquire-o, por conta própria (Programa Narrativo de aquisição reflexiva). Interessante e fundamental para a compreensão do texto é o fato de que os trapaceiros planejam seu truque para enganar o monarca justamente considerando aquilo que aos olhos do soberano lhe custaria muito, isto é, o seu "objeto mágico": peças de roupas, lindos tecidos e fazendas, o que serviram para reafirmar ainda mais a vaidade do sujeito. Sabendo disso, o antissujeito proporciona ao Rei a confecção de peças supostamente "invisíveis", "esplêndidas", "com padrão especial" para, assim, tirar-lhe ouro e linhas de seda. O Rei, neste caso, quer e pode pagar pela confecção que é feita pelos embusteiros (Programa Narrativo de aquisição transitiva) e passa a ser não só um sujeito do querer, mas também do poder, ou seja, o Rei se "atualiza". Temos um primeiro Programa de base desta narrativa (uma transformação significativa). Aqui, tem-se o início do Percurso da Ação do Sujeito. Os trapaceiros, conhecedores do valor atribuído às roupas pelo Rei, engendram uma estratégia de manipulação pelo querer-saber e pelo dever-ser. O Rei poderá ter roupas esplêndidas e invisíveis aos olhos das pessoas "destituídas de inteligência ou àquelas que não estão aptas ao cargo". Vejamos o fragmento abaixo no MN2:

"Essas fazendas devem ser esplêndidas", pensou o rei. "Usando-as poderei Disponível em: http://seer.fclar.unesp.br/casa 
descobrir quais os homens, no meu reino, que não estão em condições de ocupar seus postos, e poderei substituí-los pelos mais capazes... Ordenarei, então, que fabriquem certa quantidade deste tecido para mim.

O destinador (trapaceiros) manipula o destinatário (Rei) a fazê-lo fazer. Esta manipulação é caracterizada pela tentação (ao sujeito Rei será ofertado um valor com o qual ele compartilha) e também pela sedução - a imagem do Rei como cumpridor de um papel social de representante político de um determinado reino não pode ser maculada, ele deve ser inteligente e apto para o cargo que ocupa. Assim, o Rei interpreta (fazer interpretativo) como necessário o seu dever e o seu querer. Com o poder nas mãos, ordena que as roupas sejam fabricadas para ele. Torna-se, então, o sujeito do fazer. E se torna competente para isso. Além disso, temos outro programa de base anterior ao fechamento do percurso primeiro do sujeito do fazer (Rei) que será estabelecido por completo na sanção, ao final da narrativa. Lembremonos, então, do que diz Barros (2005, p. 191):

Cada uma das narrativas desdobradas tem uma organização canônica em que três percursos se relacionam por pressuposição: o percurso da manipulação, o da ação, e o da sanção, sendo que a sanção pressupõe a ação que, por sua vez, pressupõe a manipulação.

Dois pontos devem ser levados em consideração. O primeiro diz respeito ao virtualismo dos papéis actanciais desenvolvidos pelo Rei. Para obter o que deseja, o monarca é manipulado pelos trapaceiros e engendra outro tipo de manipulação sobre seus servos, por meio da intimidação, já que ele é um sujeito do "poder real". Assim, ele tem o poder de ordenar e mandar. Observemos:

"Ordenarei, então, que fabriquem certa quantidade deste tecido para mim." Ele não tinha propriamente dúvidas a seu respeito, mas achou melhor mandar alguém primeiro, para ver o andamento do trabalho.

- Mandarei meu velho ministro observar o trabalho dos tecelões.

Desta forma, ordena a seu velho ministro (fazer persuasivo) que observe a produção do trabalho e este, por sua vez, deve obedecer ao rei (em seu fazer interpretativo).

O segundo ponto é o fato de que, neste MN2, temos outra modalidade veridictória: a mentira, já que o antissujeito parece ser o que não é. Os impostores parecem agir verdadeiramente, mas não agem, de modo que enganam ao Rei e aos seus súditos, apresentando-lhes valores não verdadeiros. O fato é que tanto o Rei quanto o ministro não devem e não podem negar a imagem positiva que lhe é construída por meio da manipulação. Eles acreditam no fazer persuasivo do manipulador, porque não querem-ser considerados incapazes, não querem-ter sua imagem associada à incompetência e à ignorância. Neste sentido, o valor da vaidade mais uma vez se afirma. A instância do poder monárquico também compartilha do valor em jogo apresentado pelos enganadores do reino.

Passemos à análise do Momento Narrativo 3 (MN3):

Os embusteiros pediram mais dinheiro, mais seda e ouro para prosseguir o trabalho. Puseram tudo em suas bolsas. Nem um fiapo foi posto nos teares, e continuaram fingindo que teciam. Algum tempo depois, o rei enviou outro fiel oficial para olhar o andamento do trabalho e saber se ficaria pronto em breve. A mesma coisa lhe aconteceu: olhou, tornou a olhar, mas só via os teares vazios. 
— Não é lindo o tecido? Indagaram os tecelões, e deram-lhe as mais variadas explicações sobre o padrão e as cores. "Eu penso que não sou um tolo, refletiu o homem. Se assim fosse, eu não estaria à altura do cargo que ocupo. Que coisa estranha!"... Pôs-se então a elogiar as cores e o desenho do tecido e, depois, disse ao rei: "É uma verdadeira maravilha!".

Novamente, o Rei delega poderes aos seus súditos. Assim, envia outro "fiel oficial" para que veja o andamento da produção. Este também obedece ao Rei por um dever-fazer e não deve admitir que seja um oficial incompetente, pois este valor lhe é indesejável. Caso admitisse não poder ver o tecido, estaria também admitindo sua falta de aptidão para o cargo que ocupava e assim seria destituído da função que exercia. Neste MN3, a modalidade veridictória do MN2 permanece a mesma. A diferença é que o Rei (sujeito do fazer) reafirma seu poder: envia outro servo para lhe dar satisfações a respeito do tal tecido. Este também não quer ser visto como tolo, já que a ele foi atribuída uma tarefa especial. Assim, se o oficial afirmasse que nada podia ver, estaria também afirmando sua fragilidade e incapacidade. Neste momento, devemos também considerar que o Rei começa a ser manipulado pelo querer-saber. Trata-se de um sujeito curioso, que acompanhado de seus cortesões, decide visitar a sala de trabalho dos impostores. Analisemos o fragmento abaixo: "Acompanhado por um grupo de cortesões, entre os quais se achavam os dois que já tinham ido ver o imaginário tecido, foi ele visitar os dois astuciosos impostores. Eles estavam trabalhando mais do que nunca nos teares vazios".

Esta narrativa põe em jogo a manipulação que se estabelece em todos os níveis hierárquicos do reino. Não só o Rei, mas seus conselheiros e a população acreditam nos novos tecidos e na capacidade inédita dos embusteiros em criar tecidos tão valiosos e invisíveis. "Todos na cidade não falavam noutra coisa senão nessa esplêndida fazenda, de modo que o rei, muito curioso, resolveu vê-la, enquanto ainda estava nos teares".

Notamos, mais uma vez, que a vaidade ou o excesso dela é o que mantém o fluxo da narrativa. Todos os sujeitos são manipulados, porque querem ter prestígio social (tal valor é desejável) e, portanto, não podem e não devem admitir a mentira. A incompetência administrativa para o cargo, em todas as esferas de atuação, é um valor temível pelos sujeitos manipulados.

Estudaremos o Momento Narrativo 4 (MN4).

Neste MN4, o Rei continua sendo manipulado pelos embusteiros e resolve ele mesmo constatar o que se produzia nos teares. E ao perceber que nada podia ver, procede igualmente aos demais. O Rei também não admite não estar enxergando a fazenda, sob pena de ser tolo ou de não estar em condições para assumir o reinado.

O rei, que nada via, horrorizado pensou: "Serei eu um tolo e não estarei em condições de ser rei? Nada pior do que isso poderia acontecer-me!” Então, bem alto, declarou: — Que beleza! Realmente merece minha aprovação! Por nada neste mundo ele confessaria que não tinha visto coisa nenhuma.

É interessante verificarmos que o jogo de manipulações entre o sujeito e o antissujeito condiciona a dinâmica da narrativa ainda na modalidade veridictória da mentira. A estratégia de manipulação adotada pelos impostores é tão bem conduzida que eles "fazem de conta" que são manipulados pelo Rei por cumprirem uma honrosa missão, a de servir ao monarca, quando, na verdade, são justamente eles que o manipulam a fazer-fazer. Assim, como o Rei havia ordenado a confecção dos tecidos, que são postos para apreciação de seus conselheiros, ele acaba por sancionar positivamente os trapaceiros, aprovando o feito e como 
prêmio concede-lhes uma honrosa condecoração, provando-nos, desta forma, que a manipulação dos enganadores foi, de fato, bem engendrada. Trata-se de um antissujeito que desempenha muito bem o seu fazer persuasivo, já que, no plano narrativo, demonstra o poderfazer e/ou o saber-fazer. "O rei concedeu a cada um dos tecelões uma condecoração de cavaleiro, para ser usada na lapela, com o título "cavaleiro tecelão".

Este fragmento põe à prova que o Rei, verdadeiramente, crê-ser possível a produção invisível dos tecidos. Ao conceder aos trapaceiros uma condecoração, eles são recompensados (sanção pragmática) e reconhecidos (sanção cognitiva) como sujeitos confiáveis e competentes no serviço para o qual foram designados. Após aprovação, o Rei desempenha um novo Programa Narrativo de uso. Novamente, o destinador (os embusteiros) propõe ao Rei que ele vá ao desfile usando a roupa nova.

\section{- Agora, a roupa do rei está pronta.}

Sua Majestade, acompanhado dos cortesões, veio vestir a nova roupa. Os tecelões fingiam segurar alguma coisa e diziam: "Aqui está a calça, aqui está o casaco e aqui, o manto. Estão leves como uma teia de aranha. Pode parecer a alguém que não há nada cobrindo a pessoa, mas aí é que está a beleza da fazenda".

O sujeito é manipulado pelo antissujeito por meio da tentação e da sedução mais uma vez. A roupa nova é oferecida ao Rei que aceita o acordo, pois não quer negar a bajulação e atenção que lhe são dispensados pelos conselheiros, mesmo sabendo que apenas enxergava o seu corpo nu frente ao espelho. Ainda mantendo a sua perfórmance, o Rei segue nu em desfile e o povo, também não querendo parecer ser tolo, imbecil, aprova o grande feito.

Sua majestade virava-se para lá e para cá, olhando-se no espelho e vendo sempre a mesma imagem de seu corpo nu.

- Como lhe assentou bem o novo traje! Que lindas cores! Que bonito desenho! Diziam todos com medo de perderem seus postos se admitissem que não viam nada.

O povo, nas calçadas e nas janelas, não querendo passar por tolo, exclamava: - Que linda é a nova roupa do rei! Que belo manto! Que perfeição de tecido! Nenhuma roupa do rei obtivera antes tamanho sucesso!

Temos no MN4, um sujeito, aparentemente, realizado. O Rei parece ser o sujeito do fazer, porque desempenhou muito bem a sua função e é o centro das atenções de seu povo por causa da "nova roupa". Instaura-se, entretanto, em outro momento do desfile, uma ruptura na narrativa.

Trataremos, então, da análise do Momento Narrativo 5 (MN5). Neste momento, há o desenvolvimento do clímax da narrativa. Uma tensão se estabelece e a história caminha para o desfecho. Mas, a atuação de outro sujeito é fundamental para uma nova modalidade veridictória: a do segredo. Na realidade, uma criança opera uma grande transformação na narrativa. A criança é o único sujeito livre de qualquer manipulação, logo é a única que enxerga realmente o que acontece. Ela acaba por encorajar a multidão manipulada a enxergar o soberano nu e é a que apresenta o verdadeiro saber. Trata-se de um sujeito, verdadeiramente, competente que "desmascara" os impostores do reino. Assim, os trapaceiros são colocados à prova e a verdade se revela por meio da descoberta da criança. Aos olhos dela, o Rei, que não parece estar nu, verdadeiramente está sem roupas, sendo por ela julgado como coitado, digno de pena e o antissujeito que não parece ser impostor, o é de fato. 
Porém, uma criança que estava entre a multidão, em sua imensa inocência, achou aquilo tudo muito estranho e gritou: - Coitado! Ele está completamente nu! O rei está nu!

O povo, então, enchendo-se de coragem, começou a gritar:

—Ele está nu! Ele está nu!

A partir do feito da criança, a realidade se transforma e temos outra modalidade veridictória em jogo: a da verdade. O Rei, no MN5, manifesta paixões ou estados de alma por ter desempenhado papel tão ridículo. Primeiramente, sente-se furioso e depois envergonhado.

O rei, ao ouvir esses comentários, ficou furioso por estar representando um papel tão ridículo!

Depois que tudo terminou, ele voltou ao palácio, de onde envergonhado, nunca mais pretendia sair.

Somente depois de muito tempo, com o carinho e afeto demonstrado por seus cortesões e por todo o povo, também envergonhados por se deixarem enganar pelos falsos tecelões, e que clamavam pela volta do rei, é que ele resolveu se mostrar em breves aparições... Mas nunca mais se deixou levar pela vaidade e perdeu para sempre a mania de trocar de roupas a todo o momento.

Vejamos que só ao final da narrativa é que o Rei e os impostores são punidos. O sujeito é punido pelo excesso de vaidade e o antissujeito, pelo golpe aplicado ao Rei e ao povo. Os trapaceiros são desmascarados e julgados como falsos, pois agora todos sabem que eles não parecem confiáveis e nem são dignos de confiança e, por isso, são sancionados negativamente ao serem punidos pelo cumprimento de uma longa pena na prisão. Já o Rei sente-se envergonhado, pois crê ser imbecil, tolo. Os valores que outrora negava, agora the são marcas e nada pode fazer a respeito, a não ser deixar o tempo passar e ir se recuperando aos poucos da vergonha sentida publicamente.

\section{Os efeitos de sentido passionais}

Passaremos a considerar os estados de alma do sujeito do fazer, o Rei. O efeito de sentido mais evidente no discurso em análise é a paixão da vergonha. O monarca aprende a lição por meio dela. A vergonha que passa no desfile é pública, por isso mais sentida. Além disso, o Rei é um sujeito decepcionado, não verdadeiramente realizado, pois havia estabelecido um contrato fiduciário com o antissujeito (os impostores). O Rei é antes um sujeito da espera. Ele espera poder ter a roupa nova, já que valoriza exageradamente tal objeto. Ele também espera crer ser digno de vesti-la, de chamar atenção para si, de exibir-se e, desse modo, constrói um simulacro de si como um sujeito digno de usá-la. Há a construção de outro simulacro em relação aos trapaceiros, o de empregados confiáveis e responsáveis, construção esta que é, ao final da narrativa, negada. Há uma crise de confiança no desenrolar dos fatos (o sujeito inicialmente fica "furioso", paixão esta tensa e pontual na narrativa) e depois, passa a ser um sujeito em falta, envergonhado, que volta ao palácio de onde "nunca mais pretendia sair" (paixão extensa, duradoura). De acordo com Hernandes (2006, p. 240), "O contrato fiduciário é uma espécie de projeção das expectativas do sujeito. E se há expectativas, é porque simulacros foram construídos. Cada sujeito, a seu modo, institui as cláusulas que lhe são mais convenientes". 
É interessante observarmos ainda que o desmascaramento dos trapaceiros pela criança é a causa da verdadeira transformação na vida e nos valores do Rei. Este, após o golpe sofrido, passa a "se mostrar em breves aparições... Mas nunca mais se deixou levar pela vaidade e perdeu para sempre a mania de trocar de roupas a todo momento". É neste momento que o sujeito nega a vaidade e afirma a humildade. Outros valores são compartilhados por ele.

A vergonha, paixão complexa, serve-lhe como castigo, ainda mais por se tratar de um sujeito que hierarquicamente cumpria um papel social relevante em uma sociedade monárquica. Não se trata de um sujeito reparador de falta, pois não engendra uma vingança contra o antissujeito. Neste sentido, ele espera por uma reparação desapaixonada, porque, depois de algum tempo, toma conhecimento de que os golpistas foram desmascarados em outro reino e condenados à prisão e, então, torna-se um sujeito relaxado com a sanção sofrida pelo antissujeito. Segundo Barros (2005, p. 203), "De modo muito simplificado, as paixões dos textos são, assim, efeitos de sentido de organizações de modalidades, moduladas pela continuidade da tensão e do relaxamento."

O soberano passou por uma humilhação grandiosa e, por isso, sente-se rebaixado (inferioriza-se) em sua autoavaliação e na avaliação dos outros (seus súditos e o povo em geral). Ao desfilar nu em público, a paixão da vergonha intensifica-se, pois há uma superexposição de sua imagem. Verifiquemos o que Rosa (1998, p. 199) considera sobre a paixão da vergonha:

A vergonha é um sentimento a respeito de si mesmo, ou, em último caso, diz respeito a pessoas que têm laço estreito com o sujeito, a ponto de íntima identificação entre ambos. Como sentimento que diz respeito ao próprio sujeito, pode ser classificada como self-feeling, sentimento que se volta para o eu.

Ele também se torna um sujeito indigno, cujo mérito lhe é negado, não é mais o sujeito do saber e do poder, muito pelo contrário, é um sujeito de estado (alvo do rebaixamento) e tal condição é engendrada pelo sujeito operador ou o agente do rebaixamento - os trapaceiros. Assim, torna-se desonrado, perde sua honra. Ele deixa de ser superior, digno e exaltado. Passa a ser um sujeito: inferior, indigno e humilhado. Vejamos o que diz Rosa (1998, p. 202) sobre tais atributos:

Tomando-se os elementos que dão origem à vergonha e aplicando-se sobre eles o procedimento da contrariedade, é possível obterem-se os elementos constitutivos do simulacro idealizado do eu. Desse modo, obteremos a superioridade como contrário da inferioridade, a dignidade como oposta à indignidade e a exaltação como contrário da humilhação.

Sua perfórmance é, no final das contas, falha. No desfile, há uma grande sanção (a vergonha propriamente), já que o Rei expõe uma imagem contrária de si e do que ele esperava. Neste sentido, a paixão da vergonha se traduz patemicamente como um sentimento penoso. Ao mostrar-se em breves aparições após o desfile, o Rei, envergonhado, sente um desejo de ocultação, de sumir, desejo próprio daqueles que se sentem humilhados. É o sujeito da espera, o sujeito que projetou confiança no antissujeito, porque não soube bem interpretar o seu fazer persuasivo. E a vergonha é um reflexo da crise de confiança, portanto, instala-se no sujeito um sentimento de falta (conflito entre o querer-ser e o saber poder não ser). Temos, assim, um sujeito insatisfeito e decepcionado, ou seja, sem o objeto valor (privação reflexiva, já que ele mesmo renuncia o objeto valor) e afetado pela falta, respectivamente. 


\section{A inversão das categorias de base}

Retomaremos, aqui, a breve análise da inversão dos valores eufóricos (atraentes) e disfóricos (repulsivos) no desfecho deste conto.

A vaidade e a humildade são valores comportamentais de base do sujeito. O sujeito inicia a história afirmando a vaidade (ver MN1), passa boa parte do enredo valorizando-a, já que quer e pode estar em conjunção com roupas para se exibir. Ao tomar conhecimento de que poderia vestir-se de uma peça feita com fios de seda, com padrões e cores fora do comum, com os mais lindos e excêntricos tecidos, o Rei mantém este valor de forma intensa e extensa, ou seja, a vaidade é duradoura em quase todos os momentos narrativos (do MN1 ao MN4). É apenas no MN5, após a intervenção da criança, que a categoria de base se inverte. Depois da humilhação sofrida, do reconhecimento de que havia sido tolo e enganado, por dois espertalhões, e se sentindo envergonhado por ter desfilado nu publicamente, o Rei nega a vaidade, seu estado de relaxamento é contido e só, então, no desfecho da história, o sujeito afirma a modéstia e a humildade, passando esta a ser-lhe um valor atraente, de modo pontual.

\section{O nível discursivo: o mais complexo e concreto dos níveis do percurso}

Neste nível de análise, veremos mais aprofundadamente como os valores são construídos no texto, bem como as ideologias são elucidadas pelo encadeamento das figuras que, ligadas umas às outras, tornam-se a base para o estabelecimento do tema.

Em “A Roupa Nova do Rei”, a narrativa é contada na $3^{a}$ pessoa do discurso, o que lhe confere maior efeito de objetividade, distanciamento do que se enuncia. As escolhas pronominais e verbais do discurso em $3^{\mathrm{a}}$ pessoa dão ao enunciado uma característica enunciva no seu modo de dizer. Vejamos o exemplo abaixo:

Era uma vez um rei, tão exageradamente amigo de roupas novas, que nelas gastava todo o seu dinheiro. Ele não se preocupava com seus soldados, com o teatro ou com os passeios pela floresta, a não ser para exibir roupas novas. Para cada hora do dia, tinha uma roupa diferente. Em vez de o povo dizer, como de costume, com relação a outro rei: "Ele está em seu gabinete de trabalho", dizia "Ele está no seu quarto de vestir".

Entretanto, é válido notarmos que a história de Hans Christian Andersen apresenta o que Fiorin (2012a) chama de "reversibilidade de vozes", isto é, o narrador delega a voz em discurso direto aos personagens (interlocutores), em algumas passagens do texto, aproximando o leitor (enunciatário) do que se enuncia. Desse modo, o efeito de sentido é outro: com escolhas pronominais e verbais de $1^{\text {a }}$ pessoa tem-se, então, o efeito de subjetividade, de aproximação e de verdade, o que dá ao enunciado uma característica enunciativa no seu modo de dizer.

Verifica-se, assim, que, no conto de Andersen, ocorre o que Barros chama de "desembreagem interna" (informação verbal) ${ }^{2}$. Segundo a autora, a desembreagem interna é aquela em que o enunciador dá a palavra ao sujeito que conta e este pode instalar a voz no interlocutor.

\footnotetext{
2 Termo utilizado pela Profa. Dra. Diana Luz Pessoa de Barros, no Curso de Análise do Discurso, na Universidade Federal de Mato Grosso do Sul, campus de Três Lagoas, MS, em 6 março de 2013.
} 
O espaço narrativo também se caracteriza pelo distanciamento, pelo "lá" enuncivo do ambiente em que o Rei vivia, que é diferente, distante do ambiente do narrador. Trata-se de um reino, governado por um Rei também distante, longe dos problemas e questões importantes a serem resolvidas para o povo e pelo povo. O "lá" (enuncivo) do espaço narrativo traduz, de certo modo, o descaso do monarca que só se interessava em roupas para sua própria exibição. Exemplifiquemos nas passagens abaixo:

Em vez de o povo dizer, como de costume, com relação a outro rei: "Ele está em seu gabinete de trabalho", dizia "Ele está no seu quarto de vestir".

A vida era muito divertida na cidade onde ele vivia.

Depois que tudo terminou, ele voltou ao palácio, de onde envergonhado, nunca mais pretendia sair.

Quanto ao tempo narrativo da história, mais uma vez as projeções escolhidas pelo enunciador são, predominantemente, enuncivas, com uso recorrente do presente do pretérito, pretérito do pretérito e futuro do pretérito. Nos diálogos, marcados pelo discurso direto, as escolhas das marcas temporais mudam para projeções enunciativas como o uso do presente, pretérito do presente ou futuro do presente. Vejamos algumas dessas projeções em a e b, enuncivas e enunciativas, respectivamente.

a) "A vida era muito divertida na cidade onde ele vivia. Um dia, chegaram hóspedes estrangeiros ao palácio. Entre eles havia dois trapaceiros. Apresentaram-se como tecelões e gabavam-se de fabricar os mais lindos tecidos do mundo. Não só os padrões e as cores eram fora do comum, como também as fazendas tinham a especialidade de parecer invisíveis às pessoas destituídas de inteligência, ou àquelas que não estavam aptas para os cargos que ocupavam;"

b) "Mandarei meu velho ministro observar o trabalho dos tecelões. Ele, melhor do que ninguém poderá ver o tecido, pois é um homem inteligente e que desempenha suas funções com o máximo da perfeição, resolveu o rei”.

Trata-se de uma narrativa do pretérito, ou seja, o enredo se dá em um momento anterior ao momento em que se lê e no qual se toma conhecimento da história.

\section{Os temas e as figuras do discurso}

O tema da vaidade do Rei é o que centraliza a história de Andersen. É ele que recorrentemente percorre todo o enredo da narrativa. E as figuras que recobrem o tema da vaidade conferem-lhe a coerência semântica do discurso. O Rei não tinha amigos, pois era "exageradamente amigo de roupas". Percebemos de início, no primeiro parágrafo, figuras como: roupas, dinheiro, quarto de vestir. Depois, com a chegada dos trapaceiros, novas figuras compõem o tema da vaidade: os mais lindos tecidos do mundo, padrões e cores fora do comum, fazendas esplêndidas, mais cara linha de seda e ouro.

Lembremo-nos de que o Rei é o sujeito manipulado a participar de um desfile na cidade, momento em que o monarca estaria "vestido" com a sua nova roupa "maravilhosa", "magnífica", "esplêndida", "deslumbrante" e em frente ao "espelho" é convencido de que o novo traje lhe é assentado muito bem.

Em "Mais uma vez, virou-se em frente ao espelho, numa atitude de quem está mesmo apreciando alguma coisa.", o tema da vaidade é reforçado pela figura do espelho, 
figura esta que simboliza a vaidade, o exibicionismo, pois reflete a própria imagem do sujeito. São estas recorrências isotópicas que dão o efeito de veridicção e de coerência discursiva da história.

\section{Considerações finais}

A análise do percurso gerativo de sentido do conto de fadas "A Roupa Nova do Rei" foi substancial para que percebêssemos, mais aprofundadamente, quais valores estão em jogo na narrativa e como o personagem Rei passa por uma transformação significativa, após tomar conhecimento de suas próprias fragilidades humanas. Neste sentido, esta história é uma narrativa "de gente grande", que evidencia uma forte moralização em seu desfecho.

Todos os Momentos Narrativos apresentaram em sua estrutura o chamado "jogo de veridicção" muito bem demarcados. O jogo do SER e do PARECER são, claramente, o fio que conduz os valores e os comportamentos humanos em todas as esferas sociais do contexto da história. Desde o povo até a máxima expressão da soberania (Rei), todos são enganados por causa do excesso de vaidade. A vaidade cega o Rei e todos que dele dependiam seja politicamente ou funcionalmente. Tal cegueira alastra-se, quase inconscientemente, pelo reino. Todos são manipulados a enxergarem o que não existe, porque são sujeitos que acreditam poder ser superiores e poder ter competência, prestígio, reconhecimento, elogios e bajulações.

O elemento surpresa da narrativa é a criança, a única que não se deixa manipular, pois é livre de vaidades. A criança é o sujeito que desvenda a farsa, que desmascara o teatro onde todos são passíveis de serem enganados. Ela opera a grande transformação na história e a partir de sua ação, as coisas voltam, aos poucos, à normalidade, mas com outros valores, diferentes do início da história.

O Rei, afetado pela paixão da vergonha, é desonrado e inferiorizado, humilhado por enxergar às claras que foi tolo, imbecil, incompetente e inapto para o cargo que ocupa. Logo ele: o mais poderoso do reino! O próprio sujeito apaixonado tem como única saída a aceitação de sua condição inferiorizada e do seu "eu real falho", isto é, ele deixa de ser o modelo social perante seus subordinados, para assumir uma posição mais próxima do povo, assume-se então humilde, passível de erros e de falhas. Portanto, mais humano. O sujeito envergonhado tornase consciente de sua limitação diante dos outros e transforma-se por meio de um dever-ser e de um dever-fazer diferentes. Um novo simulacro de si é construído: o rei passa a ser humilde e modesto.

\section{REFERÊNCIAS}

ANDERSEN, H. C. A roupa do novo rei. Disponível em: <http://www.clubedobebe.com.br/homepage/fabulas/aroupanovadorei.htm>. Acesso em: 3 mar. 2013.

BARROS, D. L. P. Estudos do discurso. In: FIORIN, J. L. (Org.). Introdução à linguística II: princípios de análise. 4. ed. São Paulo: Contexto, 2005. p. 187-219.

HERNANDES, N. Fui enganada por um amor virtual: análise semiótica de um depoimento da revista Marie Claire. In: NOLASCO, E. C.; GUERRA, V. M. L. (Org.). Discurso, alteridades e gênero. São Carlos: Pedro \& João Editores, 2006. p. 235-251.

FIORIN, J. L. Teoria dos signos. In: FIORIN, J. L. (Org.). Introdução à linguística I: objetos teóricos. 5. ed. São Paulo: Contexto, 2006. p. 55-74.

FIORIN, J. L. Enunciação 1/5: cursos livres Univesp. Univesp TV, 16 jan. 2012a. Disponível 
em:

<http://www.youtube.com/watch?v=0FmN3h6GM80\&list=SP78E2EE496FE72765\&index=> . Acesso em: 3 mar. 2013.

FIORIN, J. L. Enunciação 2/5: cursos livres Univesp. Univesp TV, 17 jan. 2012b. Disponível em:

<http://www.youtube.com/watch?v=POa4RuzCSRM\&list=SP78E2EE496FE72765\&index=> . Acesso em: 3 mar. 2013.

FIORIN, J. L. Enunciação 3/5: cursos livres Univesp. Univesp TV, 17 jan. 2012c. Disponível em:

<http://www.youtube.com/watch?v=XbZOViCEfNg\&list=SP78E2EE496FE72765\&index=>. Acesso em: 3 mar. 2013.

FIORIN, J. L. Enunciação 4/5: cursos livres Univesp. Univesp TV, 17 jan. 2012d. Disponível em:

<http://www.youtube.com/watch?v=KIykAt4PdrM\&list=SP78E2EE496FE72765\&index=4>. Acesso em: 3 mar. 2013.

FIORIN, J. L. Enunciação 5/5: cursos livres Univesp. Univesp TV, 17 jan. 2012e. Disponível em:

<http://www.youtube.com/watch?v=i4v6iWWHG48\&list=SP78E2EE496FE72765\&index=>. Acesso em: 3 mar. 2013.

GREGOLIN, M. R. F. V. A análise do discurso: conceitos e aplicações. Alfa: Revista de Linguística, São José do Rio Preto, v. 39, p. 13-22, 1995. Disponível em: <http://seer.fclar.unesp.br/alfa/article/download/3967/3642>. Acesso em: 13 mar. 2013.

ROSA, E. B. A estrutura patêmica da paixão da vergonha. Itinerários, Araraquara, v. 12, p. 197-213, $1998 . \quad$ Disponível em: <http://seer.fclar.unesp.br/itinerarios/article/download/3091/2821>. Acesso em: 23 mar. 2013. UOL EDUCAÇÃO. Poeta e escritor dinamarquês: Hans Christian Andersen [1805-1875]. Disponível em: <http://educacao.uol.com.br/biografias/hans-christian-andersen.jhtm>. Acesso em: 13 jan. 2013.

\section{ANEXO}

\section{A ROUPA NOVA DO REI, de Hans Christian Andersen}

Era uma vez um rei, tão exageradamente amigo de roupas novas, que nelas gastava todo o seu dinheiro. Ele não se preocupava com seus soldados, com o teatro ou com os passeios pela floresta, a não ser para exibir roupas novas. Para cada hora do dia, tinha uma roupa diferente. Em vez de o povo dizer, como de costume, com relação a outro rei: "Ele está em seu gabinete de trabalho", dizia "Ele está no seu quarto de vestir".

A vida era muito divertida na cidade onde ele vivia. Um dia, chegaram hóspedes estrangeiros ao palácio. Entre eles havia dois trapaceiros. Apresentaram-se como tecelões e gabavam-se de fabricar os mais lindos tecidos do mundo. Não só os padrões e as cores eram fora do comum, como também as fazendas tinham a especialidade de parecer invisíveis às pessoas destituídas de inteligência, ou àquelas que não estavam aptas para os cargos que ocupavam.

"Essas fazendas devem ser esplêndidas", pensou o rei. "Usando-as poderei descobrir quais os homens, no meu reino, que não estão em condições de ocupar seus postos, e poderei substituí-los pelos mais capazes... Ordenarei, então, que fabriquem certa quantidade deste tecido para mim." 
Pagou aos dois tecelões uma grande quantia, adiantadamente, para que logo começassem a trabalhar. Eles trouxeram dois teares nos quais fingiram tecer, mas nada havia em suas lançadeiras. Exigiram que lhes fosse dada uma porção da mais cara linha de seda e ouro, que puseram imediatamente em suas bolsas, enquanto fingiam trabalhar nos teares vazios.

- Eu gostaria de saber como vai indo o trabalho dos tecelões, pensou o rei. Entretanto, sentiu-se um pouco embaraçado ao pensar que quem fosse estúpido, ou não tivesse capacidade para ocupar seu posto, não seria capaz de ver o tecido. Ele não tinha propriamente dúvidas a seu respeito, mas achou melhor mandar alguém primeiro, para ver o andamento do trabalho.

Todos na cidade conheciam o maravilhoso poder do tecido e cada qual estava mais ansioso para saber quão estúpido era o seu vizinho.

- Mandarei meu velho ministro observar o trabalho dos tecelões. Ele, melhor do que ninguém poderá ver o tecido, pois é um homem inteligente e que desempenha suas funções com o máximo da perfeição, resolveu o rei.

Assim sendo, mandou o velho ministro ao quarto onde os dois embusteiros simulavam trabalhar nos teares vazios. — "Deus nos acuda!" pensou o velho ministro, abrindo bem os olhos. "Não consigo ver nada!" Não obstante, teve o cuidado de não declarar isso em voz alta. Os tecelões o convidaram para aproximar-se a fim de verificar se o tecido estava ficando bonito e apontavam para os teares. O pobre homem fixou a vista o mais que pode, mas não conseguiu ver coisa alguma.

— "Céus!, pensou ele. Será possível que eu seja um tolo? Se é assim, ninguém deverá sabê-lo e não direi a quem quer que seja que não vi o tecido."

- O senhor nada disse sobre a fazenda, queixou-se um dos tecelões.

- Oh, é muito bonita. É encantadora! Respondeu o ministro, olhando através de seus óculos. O padrão é lindo e as cores estão muito bem combinadas. Direi ao rei que me agradou muito.

- Estamos encantados com a sua opinião, responderam os dois ao mesmo tempo e descreveram as cores e o padrão especial da fazenda. O velho ministro prestou muita atenção a tudo o que diziam, para poder reproduzi-lo diante do rei.

Os embusteiros pediram mais dinheiro, mais seda e ouro para prosseguir o trabalho. Puseram tudo em suas bolsas. Nem um fiapo foi posto nos teares, e continuaram fingindo que teciam. Algum tempo depois, o rei enviou outro fiel oficial para olhar o andamento do trabalho e saber se ficaria pronto em breve. A mesma coisa lhe aconteceu: olhou, tornou a olhar, mas só via os teares vazios.

- Não é lindo o tecido? Indagaram os tecelões, e deram-lhe as mais variadas explicações sobre o padrão e as cores. "Eu penso que não sou um tolo, refletiu o homem. Se assim fosse, eu não estaria à altura do cargo que ocupo. Que coisa estranha!"... Pôs-se então a elogiar as cores e o desenho do tecido e, depois, disse ao rei: "É uma verdadeira maravilha!"

Todos na cidade não falavam noutra coisa senão nessa esplêndida fazenda, de modo que o rei, muito curioso, resolveu vê-la, enquanto ainda estava nos teares. Acompanhado por um grupo de cortesões, entre os quais se achavam os dois que já tinham ido ver o imaginário tecido, foi ele visitar os dois astuciosos impostores. Eles estavam trabalhando mais do que nunca nos teares vazios.

— É magnífico! Disseram os dois altos funcionários do rei. — Veja Majestade, que delicadeza de desenho! Que combinação de cores! Apontavam para os teares vazios com receio de que os outros não estivessem vendo o tecido. 
O rei, que nada via, horrorizado pensou: "Serei eu um tolo e não estarei em condições de ser rei? Nada pior do que isso poderia acontecer-me!" Então, bem alto, declarou: - Que beleza! Realmente merece minha aprovação! Por nada neste mundo ele confessaria que não tinha visto coisa nenhuma. Todos aqueles que o acompanhavam também não conseguiram ver a fazenda, mas exclamaram a uma só voz: "Deslumbrante!" "Magnífico!" "É magnífico!" Disseram os dois altos funcionários do rei. Veja Majestade, que delicadeza de desenho! Que combinação de cores! Apontavam para os teares vazios com receio de que os outros não estivessem vendo o tecido.

Aconselharam eles ao rei que usasse a nova roupa feita daquele tecido, por ocasião de um desfile, que se ia realizar daí a alguns dias. O rei concedeu a cada um dos tecelões uma condecoração de cavaleiro, para ser usada na lapela, com o título "cavaleiro tecelão". Na noite que precedeu o desfile, os embusteiros fizeram serão. Queimaram dezesseis velas para que todos vissem o quanto estavam trabalhando, para aprontar a roupa. Fingiram tirar o tecido dos teares, cortaram a roupa no ar, com um par de tesouras enormes e coseram-na com agulhas sem linha. Afinal, disseram:

- Agora, a roupa do rei está pronta.

Sua Majestade, acompanhado dos cortesões, veio vestir a nova roupa. Os tecelões fingiam segurar alguma coisa e diziam: "Aqui está a calça, aqui está o casaco e aqui, o manto. Estão leves como uma teia de aranha. Pode parecer a alguém que não há nada cobrindo a pessoa, mas aí é que está a beleza da fazenda”.

— Sim! Concordaram todos, embora nada estivessem vendo.

- Poderia Vossa Majestade tirar a roupa? propuseram os embusteiros. Assim poderíamos vestir-lhe a nova, aqui, em frente ao espelho. O rei fez-lhes a vontade e eles fingiram vestir-lhe peça por peça. Sua majestade virava-se para lá e para cá, olhando-se no espelho e vendo sempre a mesma imagem, de seu corpo nu.

- Como lhe assentou bem o novo traje! Que lindas cores! Que bonito desenho! Diziam todos com medo de perderem seus postos se admitissem que não viam nada. O mestre de cerimônias anunciou:

- A carruagem está esperando à porta, para conduzir Sua Majestade, durante o desfile.

- Estou quase pronto, respondeu ele.

Mais uma vez, virou-se em frente ao espelho, numa atitude de quem está mesmo apreciando alguma coisa. Os camareiros que iam segurar a cauda inclinaram-se, como se fossem levantá-la do chão e foram caminhando, com as mãos no ar, sem dar a perceber que não estavam vendo roupa alguma. $\mathrm{O}$ rei caminhou à frente da carruagem, durante o desfile. $\mathrm{O}$ povo, nas calçadas e nas janelas, não querendo passar por tolo, exclamava: — Que linda é a nova roupa do rei! Que belo manto! Que perfeição de tecido! Nenhuma roupa do rei obtivera antes tamanho sucesso!

Porém, uma criança que estava entre a multidão, em sua imensa inocência, achou aquilo tudo muito estranho e gritou: — Coitado! Ele está completamente nu! O rei está nu!

O povo, então, enchendo-se de coragem, começou a gritar:

— Ele está nu! Ele está nu!

O rei, ao ouvir esses comentários, ficou furioso por estar representando um papel tão ridículo! O desfile, entretanto, devia prosseguir, de modo que se manteve imperturbável e os camareiros continuaram a segurar-lhe a cauda invisível. Depois que tudo terminou, ele voltou ao palácio, de onde envergonhado, nunca mais pretendia sair.

Somente depois de muito tempo, com o carinho e afeto demonstrado por seus cortesões e por todo o povo, também envergonhados por se deixarem enganar pelos falsos Disponível em: http://seer.fclar.unesp.br/casa 
CASA, Vol.11 n.2, dezembro de 2013

tecelões, e que clamavam pela volta do rei, é que ele resolveu se mostrar em breve aparições... Mas nunca mais se deixou levar pela vaidade e perdeu para sempre a mania de trocar de roupas a todo o momento.

Quanto aos dois supostos tecelões, desapareceram misteriosamente, levando o dinheiro e os fios de seda e ouro. Mas, depois de algum tempo, chegou a notícia na corte, de que eles haviam tentando fazer o mesmo golpe em outro reino e haviam sido desmascarados, e agora cumpriam uma longa pena na prisão. 